\title{
DO RÉS-DO-CHÃO ÀS ALTURAS: A PRESENÇA DO ART DÉCO NA ARQUITETURA DE FLORIANÓPOLIS ${ }^{1}$
}

\author{
Alice de Oliveira Viana ${ }^{2}$; Prof ${ }^{a}$. Dra Sandra Makowiecky ${ }^{3}$ \\ Palavras-chave: Art Déco; arquitetura; Florianópolis
}

\begin{abstract}
Resumo: Esta pesquisa tem como objetivo investigar a introdução da estética do Art Déco na cidade de Florianópolis, ao longo da primeira metade do século vinte, tendo como referência principal sua expressão na arquitetura da cidade. Como uma linguagem que marcou a modernidade em muitas cidades dentro e fora do país, busca estabelecer relações com o fenômeno a nível nacional e mundial.
\end{abstract}

Durante o século dezenove, podemos dizer que o indivíduo gradativamente passa a adquirir maior autoconsciência corporal, regulamentação de suas condutas e hábitos, os quais são deslocados da esfera pública para a privada. A valorização da vida íntima aparece com o interior doméstico surgindo como local de desejo e satisfação pessoal (PERROT, 1991). Pode-se justificar deste modo a emergência da valorização da casa, especialmente a burguesa, refletida no desenvolvimento das artes decorativas. Podemos afirmar que é a partir deste momento que a decoração de interiores firma-se como prática dominante de uma sociedade que buscava, dentre outras questões, transparecer, pelo acúmulo de determinados objetos, uma imagem de si.

Dentre as muitas linguagens estéticas surgidas na valorização deste interior está o Art Nouveau, no final do século dezenove, seguido do Art Déco, já nas primeiras décadas do vinte, e ambos, especialmente este último, fizeram parte de expressões da arquitetura das cidades. O Art Déco, apesar da pequena relevância historiográfica que lhe foi até então conferida, foi de grande importância ao redesenhar a paisagem da cidade moderna brasileira, através dos primeiros arranha-céus que despontavam como emblemas de progresso e modernização.

A metodologia utilizada para esta pesquisa está sendo feita através de fontes bibliográfica e documental, uma vez que está se recorrendo a arquivos com imagens de arquiteturas já existentes na cidade durante as primeiras décadas do século vinte, assim como realizando um levantamento fotográfico daqueles exemplares de linguagem Art Déco ainda existentes. Para atingir o objetivo deste trabalho, contemplam-se imagens presentes na história da arte em relação àquelas expressões encontradas na cidade de Florianópolis.

Em Florianópolis, o Art Déco, como uma linguagem arquitetônica, foi introduzido na primeira metade do século XX, mais especificamente a partir da década de trinta ${ }^{4}$. A

\footnotetext{
${ }^{\overline{1}}$ Projeto de pesquisa de pós-graduação no mestrado em Artes Visuais da UDESC PPGAV/CEART/UDESC

${ }^{2}$ Acadêmica do curso de Pós-graduação em Artes Visuais - PPGAV/CEART - UDESC. Bolsista do Programa de monitoria de Pos-graduação da UDESC -PROMOP. Email: alice_viana@yahoo.com.br ${ }^{3}$ Orientadora, professora do Programa de Pós-graduação em Artes Visuais - PPGAV/CEART - UDESC. Email:sandra@udesc.br.

${ }^{4}$ Informação obtida a partir de pesquisa em arquivo da Secretaria de Urbanismo e Serviços Públicos SUSP da cidade, onde se encontram as plantas de todos os projetos construídos na capital desde a década
} 
cidade, até então convivendo com a marcante presença luso-açoriana e eclética que compunham a paisagem predominante, começa a apresentar traços dessa expressão modernizante que já estava em andamento nas principais capitais brasileiras.

Esta estética moderna, durante a década de cinqüenta, esteve presente nos primeiros prédios em altura de Florianópolis, uma inovação para uma cidade cuja marca dominante era o pequeno casario açoriano. Ao longo das primeiras décadas do século vinte, em um contexto mundial de crescimento das cidades, os primeiros arranha-céus surgiam utilizando os benefícios do concreto armado, que proporcionava a planta livre, liberando a estrutura das suas vedações. A construção em altura, praticamente em todos os países sul-americanos, europeus, africanos e asiáticos emerge de uma tendência que já ocorria nos Estados Unidos, especialmente com a reconstrução da cidade de Chicago, vítima de um incêndio em 1871. Também foi grande a importância dos manifestos futuristas e expressionistas, que traziam novos paradigmas de cidades, primando pelo modelo da máquina e do progresso. Desta forma, temos em Florianópolis a construção do Oscar Hotel (1960), o edifício São Jorge, antigo Lux Hotel (1952), e o Banco Nacional do Comércio(1959), dentre outros, que traziam linhas retas, uma linguagem mais racionalizante e a construção em altura, representando à época, 'sonhos com uma cidade grande no futuro"(CASTRO, 2002, p.96).

Ao longo da pesquisa, o que foi possível perceber até então é que grande parte dos exemplares art déco deste período encontram-se nas ruas da centralidade principal da cidade, como Conselheiro Mafra, Fernando Machado, Francisco Tolentino, João Pinto, Felipe Schmidt, General Bittencourt e Marechal Deodoro, construídos entre a década de trinta e a de cinqüenta, o que leva-nos a entender que o crescimento da cidade nesta época ainda se restringia ao centro original, com exceção de casas de chácaras também encontradas nos arredores desta centralidade, pertencentes às famílias mais abastadas, que procuravam subtrair-se das "inconveniências" do centro urbano. Na grande maioria das imagens pesquisadas, verificou-se um déco de linguagem predominantemente geométrica, de traços simples, não apresentando quaisquer elementos figurativos, - o que algumas vezes é percebido em outras localidades-, presente mais intensamente naquelas edificações mais singelas de porta-e-janela do centro da cidade.

A cidade, enquanto produção social, deve ser percebida como um importante acervo imagético, um sistema de comunicação visual (ARGAN, 1998), e a imagem da cidade, presente principalmente através das fachadas das edificações, pode e deve ser lida e interpretada. Desta forma, entendendo que o olhar é crença, e que é através dele que conhecemos a ilusão primordial do mundo, ao olharmos para as imagens dessas pequenas edificações de porta-e-janela, apesar de seu contato com a modernidade, podemos entender que é o passado barroco que reaparece, a cenografia de um cotidiano marcado pela fé e pela tradição, inscrito fortemente por seu traço singelo, em modestas moradias, pintadas por cores de um universo ainda colonial. Essa seria talvez uma face do art déco, que, apesar de não analisada pela historiografia, constitua talvez a maior parte das expressões arquitetônicas das cidades, expressões que podemos reconhecer uma intenção comum, e que encontraram na singeleza e na linguagem geométrica sua marca dominante. Desta forma, visualmente, podemos pensar que a modernidade em Florianópolis, até a primeira metade do século vinte, apesar de seu desejo por novidade e mudança, não apresentou importantes avanços, uma vez que, em um primeiro olhar, nosso passado barroco ainda encontrava-se presente.

de vinte. Foi percebido que foram destruídos devido a um foco de incêndio no prédio, porém, a grande maioria ainda existe, apesar da precariedade de seu estado de conservação. 
Além desta tipologia predominante, encontramos a presença de traços déco também em sobrados, chalés e chácaras, e alguns, pela expressão híbrida, apropriam-se de linguagens de vários estilos diferentes, estando ainda em processo de análise.

\section{REFERÊNCIAS BIBLIOGRÁFICAS}

ARGAN, Giulio Carlo. História da arte como história da cidade. São Paulo: Martins Fontes, 1998.

CASTRO, Eloah Rocha Monteiro de. Jogo de formas híbridas. Arquitetura e modernidade em Florianópolis na década de 50. Florianópolis: tese(doutor em historia cultural) UFSC, 2002.

PERROT, Michelle. Maneiras de morar. In: PERROT, Michelle. (org). História da vida privada 4: da Revolução Francesa à Primeira Guerra. Trad. Bernardo Joffily. SP: Cia das Letras, 1991. 